\title{
OPTIMIZATION OF AQUEOUS-BASED FILM COATING PROCESS PARAMETERS CONTAINING GLUCOSAMINE SULFATE POTASSIUM CHLORIDE
}

\author{
NISHANT OZA*, AKRUTI KHODAKIYA, SWATI SAGAR
}

C. U. Shah College of Pharmacy and Research, Wadhwan City 363030, Gujarat, India

Email: ozanishant@gmail.com

Received: 07 Jan 2019, Revised and Accepted: 10 May 2019

\begin{abstract}
Objective: The aim of the present work was to prepare film-coated tablet of glucosamine sulfate potassium chloride and study the effect of coating process parameters which implicate more significant effects on an aqueous-based film coating process of tablets.

Methods: The different batches of uncoated tablets were prepared by wet granulation method. Aqueous film coating was carried out by using opadry ${ }^{\circledR}$ II white 85F18422. A $3^{2}$ full factorial design was employed to study the effect of spray rate $\left(\mathrm{X}_{1}\right)$ and inlet air temperature $\left(\mathrm{X}_{2}\right)$ on coating uniformity, coating process efficiency and \% loss on drying. The surface characteristics of the aqueous-based film-coated tablet were studied using a SEM. Check point batch was prepared to validate the evolved model.
\end{abstract}

Results: Preliminary trials indicated that individual process parameters affected the quality of coated tablets. Hence, studied the combined effect of these factors on the coating process required and $3^{2}$ full factorial design was applied. In this study, it was seen that the spray rate and inlet air temperature had a major effect on tablet coating process. It was observed from factorial batch that maximum drug release was found in batch F5.

Conclusion: The results of full factorial design indicate both parameters spray rate $\left(\mathrm{X}_{1}\right)$ and inlet air temperature $\left(\mathrm{X}_{2}\right)$ have a significant effect on coating process and batch F5 is stable for 3 mo at the accelerated condition.

Keywords: Glucosamine sulfate potassium chloride, $3^{2}$ full factorial design, Aqueous-based film, Spray rate, Inlet air temperature

(C) 2019 The Authors. Published by Innovare Academic Sciences Pvt Ltd. This is an open-access article under the CC BY license (http://creativecommons.org/licenses/by/4.0/) DOI: http://dx.doi.org/10.22159/ijap.2019v11i4.31905

\section{INTRODUCTION}

Glucosamine sulfate potassium chloride (GS-K) is a naturally occurring chemical found in the human body. It resides in human cartilage connective tissue that serves as a joint cushion in the knees, hips and joints [1,2]. It is used in the treatment of osteoarthritis. GS-K is highly hygroscopic and degrades rapidly when exposed to moisture or air. So it's creating problems in shelflife and bioavailability $[3,4]$.

Oral route of drug administration is the most appealing route for drug delivery. Among the oral dosage form tablet are most preferred dosage forms because of its ease to manufacturing, convenience in administration and accurate dosing. Film coating and sugar coating of the tablets is an additional step in the manufacturing process which increases the cost of products $[5,6]$. Film coating is carried out by using organic solvent or aqueous coating. Aqueous coating of oral solid dosage forms has rapidly replaced solvent-based coating for safety, environmental and economic reasons. In, aqueous coating processing parameters like spray rate, inlet air temperature, pan speed, atomizing air pressure are important issues $[7,8]$.

GS-K of orally administered drugs exhibit moisture sensitive characteristics that create stability problem in the aqueous coating. The slower rate of evaporation gives rise to the possibility of water penetrating; this could result in either physical degradation of the drug. So, the present work was carried out by optimizing various processing parameters and improves the stability and shelf-life of the product.

\section{MATERIALS AND METHODS}

\section{Materials and reagents}

Glucosamine sulfate potassium chloride was received as a generous gift from Jenburkt Pharmaceuticals Ltd. Sihor, Gujarat, India. Opadry II 85F18422 white was obtained from Colorcon, Goa, India. Microcrystalline cellulose (PH 101) and Microcrystalline cellulose (PH 102) were purchased from SAVA Fine Chemical, Mumbai, Maharashtra, India. All other materials and chemicals used were of either pharmaceutical or analytical grade.

\section{Drug excipients compatibility study}

The physicochemical compatibilities of drug and excipients were tested by differential scanning calorimetric (DSC) analysis. DSC thermograms of the drug and drug-excipients physical mixtures (1:1 wt/wt) were derived from a DSC with a thermal analysis performed by using an automatic thermal analyzer system (DSC 60 , Shimadzu, Japan). The analysis was performed at a rate of $10^{\circ} \mathrm{C} / \mathrm{min}$ from 50 ${ }^{\circ} \mathrm{C}$ to $250^{\circ} \mathrm{C}$ under a nitrogen flow of $20 \mathrm{ml} / \mathrm{min}[9,10]$.

Development of glucosamine sulfate potassium chloride core tablet

The tablets were formulated by wet granulation technique and the whole process like dispensing; sifting, milling and compression were done under the controlled temperature and humidity. All the ingredients were individually screened through sieve no. 60, except glidants and lubricant. Povidone K30 and methylparaben were dissolved in isopropyl alcohol (IPA) which was used as a binder. Dibasic calcium phosphate and microcrystalline cellulose (Avicel PH 101) was used as diluents. Granulation was carried out in two-liter capacity rapid mixing granulator (RMG) and drying was carried out in fluid bed dryer (FBD) until LOD was dropped below $2 \%$. Compression was carried out using 16 station "D" types tooling rotary compression machine. Composition of core formulation described in table $1[12,13]$.

\section{Preliminary screening of coating parameters}

GS-K core tablet were coated by using $10 \%$ suspension of opadry ${ }^{\circledR}$ II 85F18422 white in water. Core tablets were loaded into prewarmed coating pan. Then spray of the coating dispersion was started along with the regulation of various coating parameters like atomizing air pressure (1.8 Bar), pan speed (9-11 rpm), spray rate and inlet air temperature as described in table 3. Spraying process was continued until about 3\% weight gain was achieved on the core tablets. Then the coated tablets were dried for $15 \mathrm{~min}$ at about $50{ }^{\circ} \mathrm{C}$ of inlet air temperature $[14,15]$.

Evaluation parameters of glucosamine sulfate potassium chloride core tablet

Thickness, Hardness, Weight variation, Drug content uniformity, \% Friability and Disintegration test of the formulations were measured 
Table 1: Formulation of glucosamine sulfate potassium chloride core tablet

\begin{tabular}{|c|c|c|c|c|c|}
\hline Batch No. & T1 & T2 & T3 & T4 & T5 \\
\hline Ingredients & \multicolumn{5}{|c|}{ Quantity (mg/tablet) } \\
\hline Glucosamine sulfate potassium chloride & 750 & 750 & 750 & 750 & 750 \\
\hline Microcrystalline cellulose (Avicel PH 101) & 187.5 & 177.5 & 172.5 & 162.5 & 152.5 \\
\hline Dibasic calcium phosphate (Anhydrous) & 100 & 100 & 100 & 100 & 100 \\
\hline Methyl paraben & 0.5 & 0.5 & 0.5 & 0.5 & 0.5 \\
\hline Povidone K30 & 20 & 30 & 35 & 35 & 35 \\
\hline Isopropyl alcohol & Q. S. & Q.S. & Q. S. & Q.S. & Q. S. \\
\hline Sodium starch glycolate & 10 & 10 & 10 & 20 & 30 \\
\hline Microcrystalline cellulose (Avicel PH 102) & 25 & 25 & 25 & 25 & 25 \\
\hline Magnesium stearate & 7 & 7 & 7 & 7 & 7 \\
\hline TOTAL & 1100 & 1100 & 1100 & 1100 & 1100 \\
\hline
\end{tabular}

\section{Evaluation of coating parameters \\ Coating uniformity}

The Coating uniformity was measured as the variation in weight gain of coated tablets. The reported standard deviation (SD) was calculated as:

$$
\mathrm{SD}=\left\{\frac{\sum[(\text { wtai }- \text { wtabi })-\mathrm{x}] 2}{\mathrm{n}-1}\right\}^{\frac{1}{2}}
$$

Where, wtai and wtbi are the weights of tablet $\mathrm{i}$ after and before coating, respectively, $\mathrm{n}$ is the number of tablets measured and $\mathrm{x}$ is the average weight gain of the $n$ measured tablets from coating [20,21].

\section{$\%$ Coating process efficiency}

The \% Coating process efficiency (\% CPE) will be measured as the actual percent weight gain relative to the theoretical percent. Coating process efficiency was determined by the following equation:

$$
\mathrm{CPE}=\frac{\% \mathrm{wga}}{\% \mathrm{wgt}} \times 100
$$

Where, wgt is the theoretical percent weight gain and wga is the actual percent weight gain, before and after coating, respectively $[22,23]$.

\section{\% Loss on drying}

The \% loss on drying (\% LOD) is the moisture content of the coated tablets expressed as percent weight. The tablets were weighed, dried at $60^{\circ} \mathrm{C}$ for $24 \mathrm{~h}$ and there weighed. \%LOD was determined by the following equation:

$$
\% \text { LOD }=\left[\frac{w t b-w t a}{w t b}\right] \times 100
$$

Optimized batch surface roughness was checked by Scanning Electronic Microscopy [24, 25].

\section{In vitro drug release study}

Drug release studies were carried out by using paddle type dissolution test apparatus $\left(50 \mathrm{rpm}, 37 \pm 0.5{ }^{\circ} \mathrm{C}\right)$ for 45 minute in purified water $(900 \mathrm{ml})$. At the end of the time period, $10 \mathrm{ml}$ of the samples were withdrawal and analyzed for drug content by using HPLC method at $195 \mathrm{~nm}[26,27]$

\section{Optimization of aqueous coating process parameters by using $3^{2}$ full factorial design}

Two variables, spray rate and inlet air temperature were found critical. So, they were optimized using different trials, while other parameters were kept constant on the basis of previous coating study. On the basis of preliminary results, the coating spray rate $\left(\mathrm{X}_{1}\right)$ and the inlet air temperature $\left(\mathrm{X}_{2}\right)$ were chosen as independent variables in $3^{2}$ full factorial design, while coating uniformity (CU), coating process efficiency (CPE), \% loss on drying (\%LOD) was selected as dependent variables. Multiple linear regression analysis, ANOVA and graphical representation of the influence of factor by 3D plots were performed using of sigma plot software 11.0. The experimental runs and measured responses of $3^{2}$ full factorial design batches of Aqueous Containing of GS-K tablets were depleted in table 4 [28-30].

\section{Stability study of optimized batch}

Optimized batch was packed in blister pack and was placed for stability study at $40^{\circ} \mathrm{C} / 75 \% \mathrm{RH}$ for 3 mo. Samples were evaluated after 3-month time for in vitro drug release study. The dissolution profile of product was compared using similarity factor, $\mathrm{f}_{2}$, which was calculated by following formula.

$$
f_{2}=50 \log \left[\left\{1+\frac{1}{n} \sum_{t=1}^{n}\left(R_{t}-T_{t}\right)^{2}\right\}^{-0.5} x 100\right]
$$

Where, $\log$ is logarithm to the base $10, \mathrm{n}$ is the number of time points, $\sum$ is summation over all time points, $R_{t}$ is the mean dissolution value of the reference profile at time $t$ and $\mathrm{T}_{\mathrm{t}}$ is the mean dissolution value of the test profile at the same time point. The USFDA draft guidance document contains more information on similarity factor $\left(f_{2}\right)$. The value of similarity factor $\left(f_{2}\right)$ between 50 and 100 suggests that the two dissolution profiles are similar [31, 32].

\section{RESULTS AND DISCUSSION}

\section{Drug excipients compatibility study}

The DSC thermograph of the GS-K (fig. 1), mixture (fig. 2) Corelatated spectrum of drug and mixture (fig. 3) were obtained. The thermograph of pure GS-K showed a melting endothermic peak at $208.94{ }^{\circ} \mathrm{C}$. The thermograph of excipients showed a melting endothermic peak at $209.25^{\circ} \mathrm{C}$. The DSC thermograms of the mixer showed sharp distinct endothermic peaks for Glucosamine sulfate potassium chloride and the excipients. This indicates that the drug did not interact with excipients [33].

Evaluation of glucosamine sulfate potassium chloride core tablet

Trial batch of GS-K core tablet showed angle of repose range from 23.51-27.58, carr's index range from 6.89-18.75 and hausner's ratio range from 1.07-1.19. All the tablets passed the weight variation test and it was found within the pharmacopoeia limits. Hardness of the tablets was found to be between $2.56-6.5 \mathrm{~kg} / \mathrm{cm}^{2}$. The thickness and friability of all the formulation was found to be in the range of 5.2 to $5.7 \mathrm{~mm}$ and 0.35 to 1.2 , respectively. Disintegration time of all the formulation was found to be between 3.4 to 4.1 min was shown in table 2. The core tablets of Batch T1 and T2 failed in hardness and friability test. Batch T3 showed good hardness but disintegration time was high. Disintegration time was decreased in Batch T4 and T5 respectively. So, batch T5 was selected as a final core formulation [16-19]. 


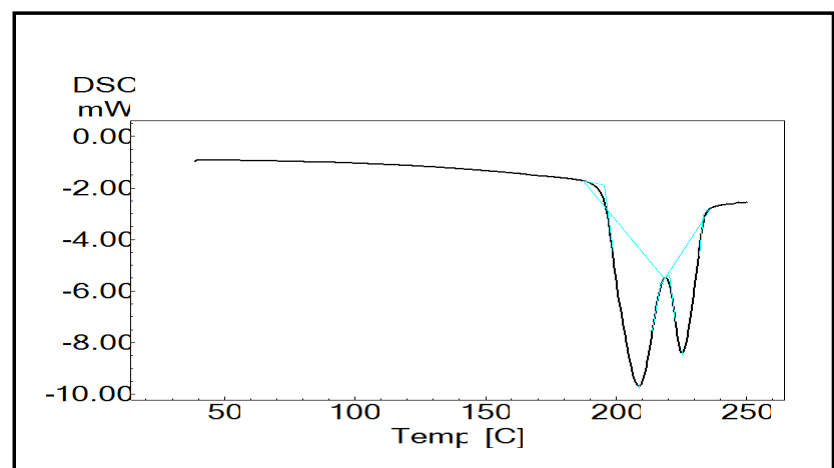

Fig. 1: DSC spectrum of glucosamine sulfate potassium chloride

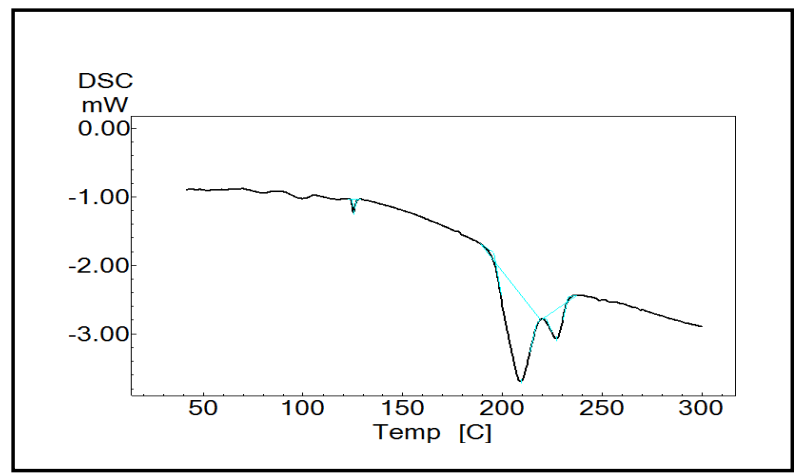

Fig. 2: DSC spectrum of the mixture

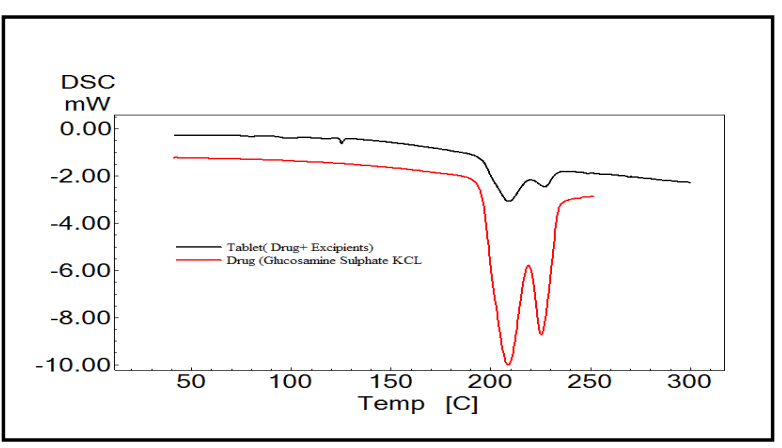

Fig. 3: DSC Co-related spectrum of drug and mixture

Table 2: Evaluation of glucosamine sulfate potassium chloride core tablet

\begin{tabular}{lllll}
\hline Batch & T1 & T2 & T3 & T4 \\
\hline Avg. Weight $(\mathrm{mg})$ & $1100 \pm 5$ & $1099 \pm 2$ & $1099 \pm 4$ & $1101 \pm 4$ \\
Hardness $\left(\mathrm{kg} / \mathrm{cm}^{2}\right)$ & $2.56 \pm 0.2$ & $4.90 \pm 0.3$ & $6.2 \pm 0.4$ & $6.4 \pm 0.4$ \\
Thickness (mm) & $5.2 \pm 0.1$ & $5.5 \pm 0.1$ & $5.4 \pm 0.2$ & $5.6 \pm 0.1$ \\
Friability (\%) & $1.2- \pm 0.3$ & $0.85- \pm 0.1$ & $0.48 \pm 0.4$ & $0.42 \pm 0.3$ \\
Disintegration Time (min) & $4.1 \pm 0.4$ & $6.3 \pm 0.2$ & $7.7 \pm 0.4$ & $5.2 \pm 0.5$ \\
\hline
\end{tabular}

All values are expressed as mean $\pm S D, n=3$

\section{Preliminary screening of coating parameters}

Two variables, spray rate and inlet Air Temperature were found critical. So, they were optimized by using different trials, while other parameters were kept constant on the basis of previous coating study. Spray rate was adjusted 5, 7, 9, 11 and $13 \mathrm{gm} / \mathrm{min}$ and the batches were designated as B1 to B5 respectively. As shown in table 2 inlet air temperature was fixed at $50{ }^{\circ} \mathrm{C}$. At a higher spray rate, sticking and picking were observed as compared to the lower spraying rates. At lower spray, rate coating efficiency was lower because the particles are dried between the paths before reaching to the tablet bed which also result in the rough surface. Batch B3 gave good surface and highest coating process efficiency thus; it was decided to use $9 \mathrm{gm} / \mathrm{min}$ spray rate in further investigations. For batch $\mathrm{B} 6$ to $\mathrm{B} 10$ inlet air temperature was adjusted $30{ }^{\circ} \mathrm{C}, 40^{\circ} \mathrm{C}, 50$ ${ }^{\circ} \mathrm{C}, 60{ }^{\circ} \mathrm{C}$ and $70{ }^{\circ} \mathrm{C}$ respectively. As shown in table 3 , Spray rate was fixed at $9 \mathrm{gm} / \mathrm{min}$. At $30{ }^{\circ} \mathrm{C}$ sticking and picking were observed because the water was not evaporated from tablet surface and tablets stuck to each other. Nozzle block was observed when inlet air temperature was kept $70{ }^{\circ} \mathrm{C}$, maybe because at the higher temperature, sprayed particles got dried very quickly. Hence, further trials were carried out using combination of inlet air temperature $\left(45{ }^{\circ} \mathrm{C}\right.$ to $55^{\circ} \mathrm{C}$ ) and spray rate $(7$ to $9 \mathrm{gm} / \mathrm{min}$ ) in order to understand their effect and to optimize coating parameters $[34,35]$.

Table 3: Preliminary screening of coating parameters

\begin{tabular}{|c|c|c|c|c|c|c|c|}
\hline Batch & $\begin{array}{l}\text { Inlet air } \\
\text { temperature }\left({ }^{\circ} \mathrm{C}\right)\end{array}$ & $\begin{array}{l}\text { Spray rate } \\
\text { (gm/min) }\end{array}$ & $\begin{array}{l}\text { Coating } \\
\text { uniformity (mg) }\end{array}$ & $\begin{array}{l}\text { \% Coating } \\
\text { process fficiency }\end{array}$ & $\begin{array}{l}\text { Surface } \\
\text { roughness }\end{array}$ & \%LOD & Conclusion \\
\hline B1 & 50 & 5 & $2.1 \pm 0.03$ & $72.58 \pm 1.2$ & 4 & $0.42 \pm 0.2$ & + \\
\hline B2 & 50 & 7 & $2.3 \pm 0.02$ & $80.45 \pm 0.4$ & 5 & $0.53 \pm 0.3$ & + \\
\hline B3 & 50 & 9 & $1.8 \pm 0.04$ & $86.62 \pm 0.8$ & 6 & $0.76 \pm 0.5$ & + \\
\hline B4 & 50 & 11 & $2.2 \pm 0.07$ & $79.85 \pm 1.7$ & 5 & $0.87 \pm 0.3$ & + \\
\hline B5 & 50 & 13 & - & - & - & - & Sticking and picking \\
\hline B6 & 30 & 9 & - & - & - & - & Sticking and picking \\
\hline B7 & 40 & 9 & $2.4 \pm 0.06$ & $79.63 \pm 1.4$ & 6 & $0.96 \pm 0.5$ & + \\
\hline B8 & 50 & 9 & $1.9 \pm 0.05$ & $87.56 \pm 1.6$ & 7 & $0.70 \pm 0.3$ & + \\
\hline B9 & 60 & 9 & $2.1 \pm 0.05$ & $81.35 \pm 0.6$ & 5 & $0.56 \pm 0.2$ & + \\
\hline B10 & 70 & 9 & $2.5 \pm 0.04$ & $68.75 \pm 1.4$ & 5 & $0.45 \pm 0.6$ & Nozzle block \\
\hline
\end{tabular}

All values are expressed as mean $\pm \mathrm{SD}, \mathrm{n}=3$ 
Table 4: Runs and measured responses of $3^{2}$ factorial design of aqueous coating process parameters

\begin{tabular}{|c|c|c|c|c|c|}
\hline $\begin{array}{l}\text { Batch } \\
\text { code }\end{array}$ & Spray rate $\left(\mathrm{X}_{1}\right)$ & Inlet air temperature $\left(\mathrm{X}_{2}\right)$ & Coating uniformity $\left(\mathrm{Y}_{1}\right)$ & Coating process efficiency $\left(\mathrm{Y}_{2}\right)$ & \% Loss on drying $\left(\mathrm{Y}_{3}\right)$ \\
\hline F1 & -1 & -1 & 1.92 & 80.42 & 0.51 \\
\hline F2 & 0 & -1 & 2.03 & 76.26 & 0.59 \\
\hline F3 & 1 & -1 & 2.19 & 72.86 & 0.53 \\
\hline F4 & -1 & 0 & 1.98 & 88.29 & 0.61 \\
\hline F5 & 0 & 0 & 2.12 & 86.45 & 0.7 \\
\hline F6 & 1 & 0 & 2.27 & 80.56 & 0.68 \\
\hline F7 & -1 & 1 & 2.11 & 78.58 & 0.62 \\
\hline F8 & 0 & 1 & 2.28 & 73.65 & 0.71 \\
\hline F9 & 1 & 1 & 2.36 & 70.35 & 0.69 \\
\hline \multicolumn{6}{|c|}{ Factors and the levels in the design } \\
\hline \multicolumn{3}{|c|}{ Independent variables } & $\operatorname{Low}(-1)$ & Medium (0) & High (1) \\
\hline \multicolumn{3}{|c|}{ Spray rate $\left(\mathrm{X}_{1}\right)$} & 7 & 9 & 11 \\
\hline \multicolumn{3}{|c|}{ Inlet air temperature $\left(\mathrm{X}_{2}\right)$} & 45 & 50 & 55 \\
\hline
\end{tabular}

\section{$3^{2}$ Full factorial design model evaluation}

A statistical model incorporating interactive and polynomial terms was used to evaluate the responses:

$$
\mathrm{Y}=\mathrm{b}_{0}+\mathrm{b}_{1} \mathrm{X}_{1}+\mathrm{b}_{2} \mathrm{X}_{2}+\mathrm{b}_{11} \mathrm{X}_{1}{ }^{2}+\mathrm{b}_{22} \mathrm{X}_{2}{ }^{2}+\mathrm{b}_{12} \mathrm{X}_{1} \mathrm{X}_{2}
$$

Where, $\mathrm{Y}$ is the dependent variable, $\mathrm{b}_{\mathrm{o}}$ is the arithmetic mean response of the 9 runs and any bi is the estimated coefficients for the related factor $\mathrm{X}_{\mathrm{i}}$. The main effects $\left(\mathrm{X}_{1}\right.$ and $\left.\mathrm{X}_{2}\right)$ represent the average result of changing one factor at a time from its low to high value. The polynomial terms $\left(\mathrm{X}_{1}{ }^{2}\right.$ and $\left.\mathrm{X}_{2}{ }^{2}\right)$ are included to investigate nonlinearity. The interaction term " $\mathrm{X}_{1} \mathrm{X}_{2}$ " shows how the response changes when the two factors change simultaneously. Evaluation data for core tablets and coated tablets were presented in table 5 and 6 respectively. The fitted equations relating the responses that is, coating uniformity (CU), coating process efficiency (CPE) and \% loss on drying (\%LOD) to the transformed factor are shown in table 4. The polynomial equations can be used to draw conclusions after considering the magnitude of coefficient and the mathematical sign it carries (i.e. positive or negative). The results of ANOVA suggested that $\mathrm{F}$ values calculated for CU, CPE and \% LOD are 50.980, 55.714 and 84.632 respectively (table 7 ). Tabulated $F$ value was found to be
9.013 at $\alpha=0.05$. Calculated $F$ values are greater than tabulated for all dependent variables, therefore, factors selected have shown significant effects. From the results of multiple regression analysis, it was found that all factors had a statistically significant influence on all dependent variables as $\mathrm{p}<0.05$ (table 8) [36, 37].

\section{Full and reduced model for coating uniformity}

The coating uniformity for coated tablets was found to be varied from 1.92 to 2.36 and it showed a good correlation coefficient of 0.988 . From the graph (fig. 4) and the regression coefficient values of factors, it was concluded that the spray rate gives more effect on coating uniformity as compared to inlet air temperature. For coating uniformity, the significance levels of the coefficients $b_{11}, b_{22}$, and $b_{12}$ were found to be $\mathrm{P}=0.727,0.804$ and 0.268 respectively, so they were omitted from the full model to generate a reduced model. The $P$ value for variable $X_{1}$ and $X_{2}$ were found 0.001 and 0.002 respectively $(\mathrm{P}<0.05)$, which indicate that $\mathrm{X}_{1}$ and $\mathrm{X}_{2}$ both variable shown a significant effect on coating uniformity [36, 37]. Hence they were retained in the reduced model. The reduced model for coating uniformity:

$$
C U=2.127+0.135 X_{1}+0.102 X_{2}
$$

\begin{tabular}{|c|c|c|c|c|c|}
\hline $\begin{array}{l}\text { Powder } \\
\text { blend }\end{array}$ & Hardness $\left(\mathrm{kg} / \mathrm{cm}^{2}\right)$ & $\begin{array}{l}\text { Thickness } \\
\text { (mm) }\end{array}$ & Friability (\%) & Avg. wt. (mg) & Disintegration time (min) \\
\hline F1 & $6.1 \pm 0.13$ & $5.7 \pm 0.13$ & $0.450 \pm 0.2$ & $1100 \pm 0.9$ & $3.2 \pm 0.5$ \\
\hline $\mathrm{F} 2$ & $6.5 \pm 0.21$ & $5.6 \pm 0.21$ & $0.448 \pm 0.4$ & $1101 \pm 0.7$ & $3.3 \pm 0.8$ \\
\hline F3 & $6.0 \pm 0.09$ & $6.0 \pm 0.09$ & $0.506 \pm 0.7$ & $1098 \pm 1.1$ & $3.3 \pm 0.4$ \\
\hline $\mathrm{F} 4$ & $5.8 \pm .32$ & $5.8 \pm .32$ & $0.656 \pm 0.2$ & $1100 \pm 1.2$ & $3.4 \pm 0.6$ \\
\hline F5 & $6.4 \pm 0.24$ & $5.9 \pm 0.24$ & $0.394 \pm 0.6$ & $1100 \pm 0.9$ & $3.4 \pm 0.4$ \\
\hline F6 & $5.9 \pm 0.17$ & $5.7 \pm 0.17$ & $0.436 \pm 0.3$ & $1102 \pm 1.1$ & $3.5 \pm 0.6$ \\
\hline F7 & $5.9 \pm 0.27$ & $5.9 \pm 0.27$ & $0.353 \pm 0.4$ & $1102 \pm 0.9$ & $3.5 \pm 0.8$ \\
\hline F8 & $6.4 \pm 0.34$ & $5.8 \pm 0.34$ & $0.459 \pm 0.1$ & $1100 \pm 0.8$ & $3.2 \pm 0.6$ \\
\hline F9 & $5.8 \pm 0.14$ & $6.1 \pm 0.14$ & $0.567 \pm 0.5$ & $1101 \pm 1.2$ & $3.4 \pm 0.4$ \\
\hline
\end{tabular}

Table 5: Evaluation of core tablets for factorial batches

All values are expressed as mean $\pm S D, n=3$

\begin{tabular}{|c|c|c|c|c|c|}
\hline $\begin{array}{l}\text { Factorial } \\
\text { batches }\end{array}$ & $\begin{array}{l}\text { Hardness } \\
\left(\mathrm{kg} / \mathrm{cm}^{2}\right)\end{array}$ & $\begin{array}{l}\text { Thickness } \\
\text { (mm) }\end{array}$ & $\begin{array}{l}\text { Avg. wt. } \\
\text { (mg) }\end{array}$ & $\begin{array}{l}\text { Disintegration } \\
\text { time (min) }\end{array}$ & $\%$ Drug release at $45 \mathrm{~min}$ \\
\hline F1 & $6.7 \pm 0.13$ & $6.3 \pm 0.10$ & $1123 \pm 0.9$ & $3.5 \pm 0.6$ & $81.47 \pm 1.6$ \\
\hline $\mathrm{F} 2$ & $7.1 \pm 0.21$ & $6.1 \pm 0.13$ & $1121 \pm 1.1$ & $3.7 \pm 0.8$ & $79.12 \pm 1.5$ \\
\hline F3 & $6.9 \pm 0.09$ & $6.4 \pm 0.12$ & $1124 \pm 1.2$ & $3.8 \pm 0.5$ & $75.83 \pm 0.7$ \\
\hline F4 & $6.8 \pm 0.32$ & $6.1 \pm 0.06$ & $1120 \pm 0.8$ & $3.2 \pm 0.8$ & $82.68 \pm 1.5$ \\
\hline F5 & $7.0 \pm 0.24$ & $6.5 \pm 0.02$ & $1123 \pm 0.6$ & $3.5 \pm 0.5$ & $86.24 \pm 0.7$ \\
\hline F6 & $6.9 \pm 0.17$ & $6.1 \pm 0.14$ & $1118 \pm 0.9$ & $3.6 \pm 1.0$ & $81.24 \pm 1.3$ \\
\hline F7 & $7.3 \pm 0.27$ & $5.8 \pm 0.06$ & $1124 \pm 1.2$ & $3.4 \pm 0.6$ & $79.57 \pm 1.2$ \\
\hline F8 & $7.1 \pm 0.34$ & $6.2 \pm 0.04$ & $1123 \pm 0.8$ & $3.6 \pm 0.7$ & $76.82 \pm 1.1$ \\
\hline F9 & $6.9 \pm 0.14$ & $6.4 \pm 0.07$ & $1122 \pm 0.9$ & $3.8 \pm 0.4$ & $73.2 \pm 1.8$ \\
\hline
\end{tabular}

Table 6: Evaluation of coated tablets for factorial batches

All values are expressed as mean $\pm S D, n=3$ 


\section{Full and reduced model for coating process efficiency}

Coating process efficiency of coated tablets was found to be varied from 70.35 to 88.29 and it's showed good correlation co-efficient of 0.989 . For coating process efficiency, as seen from fig. 5, the 3D plot reveled that a corresponding increase spray rate, there were decreases in coating process efficiency and corresponding increase in inlet air temperature there also decreased the coating process efficiency. From regression, it is observed that only $\mathrm{X}_{1}$ and $\mathrm{X}_{2}{ }^{2}$ were significant model terms which affect the coating process efficiency. Interaction and nonlinearity was not observed. The $\mathrm{P}$ value for variable $\mathrm{X}_{1}$ and $\mathrm{X}_{2}{ }^{2}$ were 0.003 and $0.001(\mathrm{P}<0.05)$, which indicate that both variable has a significant effect on the coating process efficiency [36, 37]. Hence they were retained in the reduced model. The reduced model for Coating process efficiency:

$C P E=85.284-3.920 X_{1}-9.747 X_{2}^{2}$

Table 7: Analysis of variance (ANOVA) of dependent variable

\begin{tabular}{|c|c|c|c|c|c|}
\hline Source of variation & DF & SS & MS & F value & P Value \\
\hline \multicolumn{6}{|c|}{ CU Dependent variable } \\
\hline Regression & 5 & 0.173 & 0.034 & & \\
\hline Residual & 3 & 0.002 & 0.0006 & 50.980 & 0.004 \\
\hline Total & 8 & 0.175 & 0.021 & & \\
\hline \multicolumn{6}{|c|}{ CPE Dependent variable } \\
\hline Regression & 5 & 290.532 & 58.106 & & \\
\hline Residual & 3 & 3.129 & 1.043 & 55.714 & 0.004 \\
\hline Total & 8 & 293.661 & 36.708 & & \\
\hline \multicolumn{6}{|c|}{ \% LOD Dependent variable } \\
\hline Regression & 5 & 0.043 & 0.008 & & \\
\hline Residual & 3 & 0.0003 & 0.0001 & 84.632 & 0.002 \\
\hline Total & 8 & 0.043 & 0.005 & & \\
\hline
\end{tabular}

Table 8: Summary of multiple regression analysis for coating process parameters

\begin{tabular}{|c|c|c|c|c|c|c|c|c|}
\hline \multirow{2}{*}{ Responses } & \multirow[t]{2}{*}{ Model } & \multicolumn{7}{|c|}{ Coefficient of regression parameters } \\
\hline & & $\mathbf{b}_{0}$ & $\mathbf{b}_{1}$ & $\mathbf{b}_{2}$ & $\mathbf{b}_{11}$ & $\mathbf{b}_{22}$ & $\mathbf{b}_{12}$ & $\mathbf{R}^{2}$ \\
\hline \multirow[t]{2}{*}{ coating uniformity } & Full & 2.127 & 0.135 & 0.102 & -0.005 & 0.005 & -0.025 & 0.988 \\
\hline & Reduced & 2.127 & 0.135 & 0.102 & - & - & - & - \\
\hline \multirow[t]{2}{*}{ coating process efficiency } & Full & 85.284 & -3.920 & -1.160 & -0.167 & 0.277 & -9.747 & 0.989 \\
\hline & Reduced & 85.284 & -3.920 & - & - & - & -9.747 & - \\
\hline \multirow[t]{2}{*}{ \%Loss on drying } & Full & 0.703 & 0.0267 & 0.065 & 0.012 & 0.060 & 0.055 & 0.993 \\
\hline & Reduced & 0.703 & 0.0267 & 0.065 & - & 0.060 & 0.055 & - \\
\hline
\end{tabular}

\section{Full and reduced model for \% loss on drying}

The \% LOD of coated tablets was found to be varied from 0.51 to 0.71 and showed good correlation co-efficient of 0.993 . For \% LOD, as seen from fig. 6, the 3D plot reveled that a corresponding increase in spray rate, there was increase in \% Loss on drying and the corresponding increase in inlet air temperature there was also increase in the \% loss on drying. From regression, it is observed that $\mathrm{X}_{1}, \mathrm{X}_{2}, \mathrm{X}_{1}{ }^{2}$ and $\mathrm{X}_{2}{ }^{2}$ were significant model terms which affect the \% loss on drying. Interaction and nonlinearity were not observed. The $P$ value for variable $X_{1}, X_{2}, X_{1}^{2}$ and $X_{2}^{2}$ were $0.008,0.001,0.004$ and 0.005 respectively $[36,37]$. Hence they were retained in the reduced model. The reduced model for \%Loss on drying

$$
\% L O D=0.703+0.0267 X_{1}+0.0650 X_{2}-0.0600 X_{1}^{2}-0.0550 X_{2}^{2} \text {. }
$$

\section{Validation of the design}

To validate the evolved mathematical models (reduced models) one checkpoint was selected as shown in table 9. Good correlation was found between observed and predicted values as shown in table 10 .
Hence, it was concluded that the evolved models may be used for theoretical prediction of responses within the factor space [36, 37].

\section{Selection of optimized batch in factorial design study}

Drug release of all batches was carried out for $45 \mathrm{~min}$. It was observed that (as shown in table no 5) maximum drug release was found in batch F5 and other all batches gave less drug release as compared to batch F5. Hence, batch F5 was selected as an optimized batch. The optimized formulation was subjected to SEM and accelerated stability study.

\section{Stability study of optimized batch}

Short term accelerated stability study showed that there was no significant change in the formulation after 3 mo and the evaluation result was found within the limit. The results are shown in table 11. Batch $\mathrm{F}_{5}$ was kept for the stability study. The in vitro release profile at initial and after 3 mo was compared using similarity factor, $\mathrm{f}_{2}$, value which was found to be 88.50 . There is no significant difference in similarity factor, $f_{2}$, value which indicated that the prepared formulation was stable [38].

Table 9: Formulation of checkpoint batches

\begin{tabular}{|c|c|c|c|c|}
\hline \multirow[t]{3}{*}{ Batch code } & \multicolumn{4}{|c|}{ Variable level } \\
\hline & \multicolumn{2}{|c|}{ Coded value } & \multicolumn{2}{|c|}{ Actual value } \\
\hline & $X_{1}$ & $\mathbf{X}_{2}$ & $X_{1}(\mathrm{mg})$ & $X_{2}(\mathrm{ml})$ \\
\hline CP1 & -0.5 & -0.5 & 8 & 47.5 \\
\hline
\end{tabular}

Table 10: Evaluation of checkpoint batches and comparison with predicted value

\begin{tabular}{lll}
\hline Parameter & Actual value & Predicted value \\
\hline coating uniformity & 2.1 & 2.008 \\
coating process efficiency & 79.23 & 78.450 \\
\% loss on drying & 0.721 & 0.714 \\
\hline
\end{tabular}




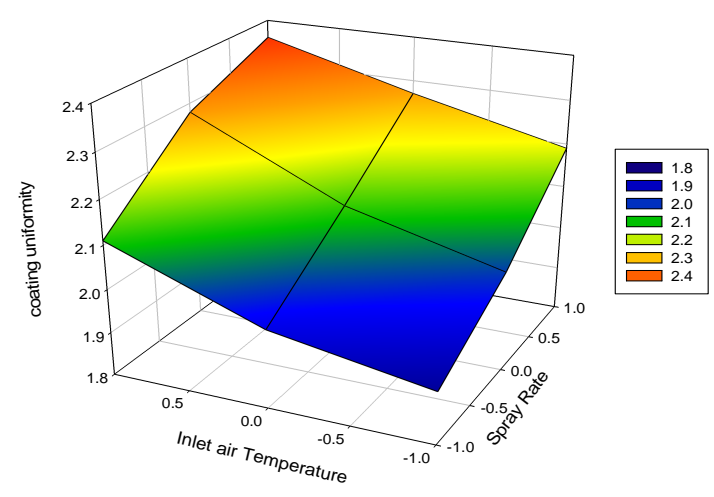

Fig. 4: Effect of spray rate $\left(X_{1}\right)$ inlet air temperature $\left(X_{2}\right)$ on coating uniformity

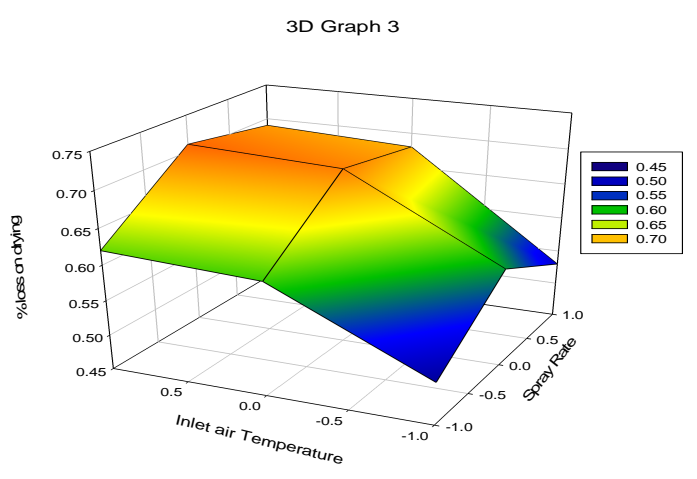

Fig. 6: Effect of spray rate $\left(X_{1}\right)$ inlet air temperature $\left(X_{2}\right)$ on \% loss on drying.

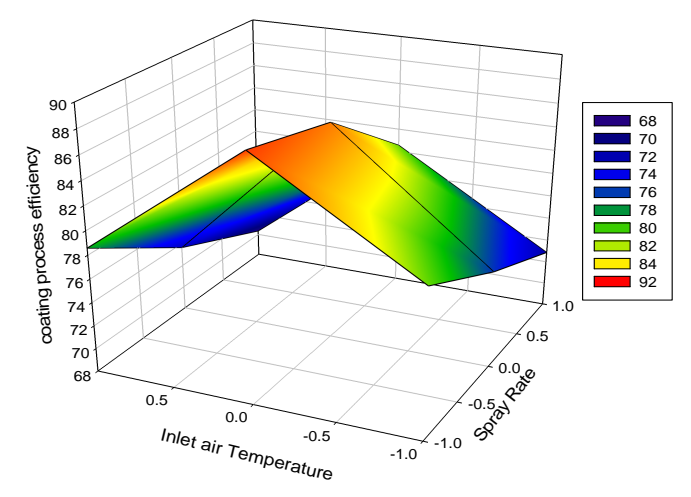

Fig. 5: Effect of spray rate $\left(X_{1}\right)$ inlet air temperature $\left(X_{2}\right)$ on coating

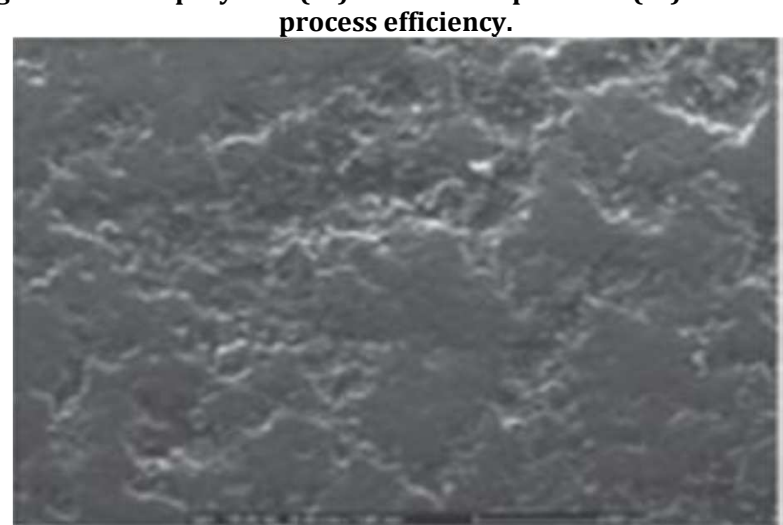

Fig. 7: SEM of coated tablet surface

Table 11: Comparative study of optimized batch with market product

\begin{tabular}{llll}
\hline S. No. & Parameters & Initial (Batch F5) & After 3 mo (Batch F5) \\
\hline 1 & Hardness $\left(\mathrm{kg} / \mathrm{cm}^{2}\right)$ & $7.0 \pm 0.21$ & $6.8 \pm 0.14$ \\
2 & Average weight $(\mathrm{mg})$ & $1123 \pm 1.3$ & $1121 \pm 0.7$ \\
3 & Disintegration time (min) & $3.5 \pm 0.3$ & $3.4 \pm 0.4$ \\
4 & Assay & $99.50 \pm 0.4 \% \mathrm{w} / \mathrm{w}$ & $98.90 \pm 0.5 \% \mathrm{w} / \mathrm{w}$ \\
5 & In vitro drug release (After $45 \mathrm{~min})$. & $86.24 \pm 1.5$ & $83.70 \pm 1.5$ \\
\hline
\end{tabular}

All values are expressed as mean $\pm S D, n=3$

\section{CONCLUSION}

In this study, an aqueous-based film coating process of glucosamine sulfate potassium chloride tablets was performed in a side-vented perforated pan coating apparatus (auto coater). The preliminary results revealed that spray rate, and inlet air temperature had a major effect on tablet coating performances. The spray rate of coating solution $9 \mathrm{gm} / \mathrm{min}$ and inlet air temperature $50{ }^{\circ} \mathrm{C}$ considered as an optimum aqueous film coating of special shaped tablets in auto coater coating machine. An optimized batch was found stable. It showed that aqueous based film coating process is compatible with the drug. Moreover, the process of film coating in developed formulation is ecofriendly, non-hazardous and cost-effective.

\section{AUTHORS CONTRIBUTIONS}

All the author have contributed equally

\section{CONFLICT OF INTERESTS}

Declared none

\section{REFERENCES}

1. Sham MM, Azmi NS, Rahim MH. Review: glycosaminoglycans versus cancer. J Environ Bioremed Toxicol 2014;2:58-61.
2. Zahari CN, Azmi NS. Halal source of medication: glycosaminoglycan derived medicinal plant. Int J Appl Chem 2016;12:803-10.

3. Choocheep K, Saenkham C, Borwornchaiyarit S, Chaiisaraseree $\mathrm{K}$, Chimchai J, Moonpa T. Investigation of sulfated glycosaminoglycans and their agarose gel electrophoresis patterns from plants extracts. J Assoc Med Sci 2018;51:11-8.

4. Vidhyanandhini R, Saravanan R, Vairamani S, Shanmugam A. The anticoagulant activity and structural characterization of fractionated and purified glycosaminoglycans from venerid clam meretrix casta. J Liq Chromatogr Related Technol 2014;37:917-29.

5. Lieberman H, Lachman L, Schwartz J. Pharmaceutical dosage form: tablets. Vol. 1. $2^{\text {nd }}$ ed. New York: Marcel dekker; 1989. p. 214-20.

6. Aultan M. The science of dosage form design. $2^{\text {nd }}$ ed. Spain: Churchill Livingstone; 2001. p. 133-5.

7. Narasimha Rao R, Anusha RM, Swetha RN, Divyasagar P, Keerthana K. Design and evaluation of metformin hydrochloride extended release tablets by direct compression. Int J Res Pharm Biomed Sci 2011;2:1118-33.

8. Gawali P, Gupta A, Kachare S, Kshirsagar S. Formulation and evaluation of matrix-based sustained release tablets of quetiapinefumarate and the influence of excipients on drug release. J Chem Pharm Res 2012;4:3073-81. 
9. Carlson E, Chandler W, Galdo I, kudla T, Ta C. Automated integrated forced degradation and drug-excipients compatibility studies. J Assoc Lab Autom 2005;10:374-80.

10. Karin Liltorp, Trine Gorm Larsen, Birgitte Willumsen, Rene Holm. Solid state compatibility studies with tablet excipients using non thermal methods. J Pharm Biomed Anal 2011;55:424-8.

11. Viveksarathi K, Rajarajan R, Kannan K, Manavalan R. Dosage form design and evaluation of eperisone hydrochloride matrix film coated extended release tablets. Int J Pharm Pharm Sci 2012;4:575-81.

12. Swain RP, TR Kumari, S Panda. Formulation development and evaluation of sustained release ibuprofen tablets with acrylic polymers and HPMC. Int J Pharm Pharm Sci 2016;8:131-5.

13. Raghuram K, Srinivas M, Srinivas R. Once-daily sustained release matrix tablets of nicorandil: formulation and in vitro evaluation. AAPS PharmSciTech 2003;4:1-9.

14. Hadisoewignyo L, L Soegianto, M Ervina, I Wijaya, SD Santoso, $\mathrm{N}$ Tania, et al. Formulation development and optimization of tablet containing combination of salam and sambiloto ethanolic extracts. Int J Pharm Pharm Sci 2016;8:267-73.

15. Pahwa R, Gupta N. Superdisintegrants in the development of orally disintegrating tablets: a review. Int J Pharm Sci Res 2008;2:2767-80.

16. Yadav K, Yadav D, Srivastava A. Evaluation of hydrophilic, hydrophobic and waxy matrix excipients for sustained release tablets of venlafaxine hydrochloride. Drug Dev Ind Pharm 2013;39:1197-206.

17. Khar RK, Mohapatra S, Barik BB. Design and characterization of controlled release matrix tablets of zidovudine. Asian J Pharm Clin Res 2009;2:54-61.

18. Madgulkar AR. Formulation and optimization of sustained release tablets of venlafaxine resinates using response surface methodology. Indian J Pharm Sci 2009;71:387-94.

19. Lakade SH, Bhalekar MR. Formulation and evaluation of sustained release matrix tablet of anti-anginal drug influence of combination of hydrophobic and hydrophilic matrix former. Res J Pharm Technol 2008;1:410-1.

20. Jordan MP, Rajabi Siahboomi AR. Influence of film coatings on performance of hypromellose matrices. Eur Pharm Rev 2000;1:12-21.

21. Okutgen E, Jordan M, Hogan JE, Aulton ME. Effects of tablet core dimensional instability on the generation on internal stress within film coat part temperature and relative humidity variation within a tablet bed during aqueous film coating in an accela-cota. Drug Dev Ind Pharm 1991;17:1191-9.
22. Tobiska S, Kleinebudde P. Coating uniformity: influence of atomizing air pressure. Pharm Dev Technol 2003;8:39-46.

23. Obara S, Mc Ginity. Influence of processing variables on the properties of free films prepared from aqueous polymeric dispersions by a spray technique. Int J Pharm 1995;126:1-10.

24. Aoki S. Preparation composition containing acid unstable physiologically active compound and process for producing same. U. S Patent No. US 2005/0163846 A1; 2005.

25. Tobiska S, Kleinbudde PA. Simple method for evaluating the mi xing efficiency of a new type of pan coater. Int J Pharm 2001;22 4:141-9.

26. Kumar S, A Nanda. Formulation, optimization and in vitro evaluation of gastroretentive mucoadhesive microspheres of furosemide. Int J Pharm Pharm Sci 2016;8:392-8.

27. Siepmann J, Peppas NA. Modelling of drug release from delivery systems based on hydroxypropyl methylcellulose. Adv Drug Delivery Rev 2001;48:139-57.

28. Costa P, Lobo JM. Modeling and comparison of dissolution profiles. Eur J Pharm Sci 2001;13:123-33.

29. Gohel M, Patel M, Agarwal R, Amin A, Dave R, Bariya N. Formulation design and optimization of mouth dissolving tablets of nimesulide using vacuum drying technique. AAPS PharmSciTech 2004;5:36-42.

30. Patel KJ, Dharamsi A. Formulation development and optimisation of controlled release microspheres of aceclofenac using response surface methodology. J Chem Pharm Res 2015;7:88-99.

31. Guideline ICH. Stability testing guidelines: stability testing of new drug substances and products. ICH Q1A (R2) (CPMP/ICH/2736/99); 1999.

32. Stability testing of new drug substances and products [Q1A (R2)]. The International Conference on Harmonisation of Technical Requirements for Registration of Pharmaceuticals for Human Use; 2003.

33. Vogel AI. Vogel's textbook of quantitative chemical analysis. 5th ed. Jeffrey GH, Bassett J, Mendham J, Denney R. editors; 1989. p. 220-5.

34. Patel J, Shah A, Sheth N. Aqueous-based film coating of tablets: study the effect of critical process parameters. Int J Pharm Tech Res 2009;1:235-40.

35. Cahyadi C, Heng PWS, Chan LW. Optimization of process parameters for a quasi-continuous tablet coating system using design of experiments. AAPS PharmSciTech 2011;12:119-31.

36. Bolton S, Bon C. Pharmaceutical statistics: practical and clinical applications. $5^{\text {th }}$ ed. Informa Healthcare; 2005. p. 472-93.

37. Lewis GA, Mathieu D, Phan-Tan-Luu R. Pharmaceutical experimental design. New York: Marcel Dekker; 1999. p. 191-8.

38. BP British Pharmacopoeia. Stationary Office 2009;2010:3045-9. 